\title{
Epigenetic (protein) patteren of albino rat Rattus norvegicus after treatment with homocysteine and trimethylglycine.
}

\section{Sahar Abd El-Razik Mosallam}

Department of Zoology, Girls Collage for Arts, Scie. and Education, Ain Shams Univ. ABSTRACT

Hyperhomocysteineamia (hHcys) is thought to be a risk factor for cardiovascular disease. The epigenetic (protein) pattern due to the effect of hHcys in kidney and liver was profiled in the supplemented developing rats. A group treated with $0.6 \%$ Hcys for 8 weeks and trimethylglycine (Tri or Betaine) antioxidant treated group $(6 \mathrm{~g} / \mathrm{Kg}$ ) were compared with four weeks age control group. The results indicated that, a great variety in protein pattern was obtained. Specific type of protein with M.W. of $214.29 \mathrm{~K}$. d. was produced in the kidney samples treated with Trimethylglycine. Common types of protein with M.W. of 278.64, 157.07, 52.39, $39.31,29.24,24.49,20.86,20$ and $18.87 \mathrm{~K}$. d. were obtained in the same sample. Characteristic band with $59.58 \mathrm{~K}$. d. was obtained in control the kidney after 8 weeks while three types of protein were obtained in the control liver with M.W. of 221.4, 28.25 and 18.07 K.d. The highest similarity index was between control and Trimethylglycine treated kidney group (0.76), but the lowest one was between the control and liver trimethylglycine treated group $(0.38)$.

Key words: Homocysteine, trimethyleglycine (betaine) and rats.

\section{INTRODUCTION}

Hyperhomocysteineamia (hHcys) has been indicated as an independent risk factor causing a variety of pathological changes in different cells or tissues. Homocysteine (Hcys) is produced from S- adenosylhomocysteine (SAH) through the catalysis of (SAH) hydrolase, ( $\mathrm{Li}$ et al., 2006). Hcys is derived from the essential amino acid methionine, during normal condition, excess Hcys is converted back to methionine or broken down be excreted (Stead et al., 2000). While the remethylation process of Hcys was 5-methyltetrahydrofolate and the activity of betaine homocystein S-methyltransferase (BHMT) as the methyl donor (Finkelstein et al., 1971; Castro et al., 2002 and Finkelstein, 2007). In rat, the kidney is a major site for the removal of plasma Hcys House et. al, 1997 B \& 1999. According to Stead et al., 2000, the liver is a key organ of Hcys metabolism and potentially control the plasma Hcys level. Betaine was involved in Hcys metabolism as an alternative methyl donor, it is used in the treatment of homocystineuria in human as revealed by Schwab et al., 2002. Betaine is found naturally in most living organisms, it protects plants (Sakamoto and Murata, 2000), microbes (Rozwadowski et al., 1991), marine and freshwater invertebrates (Konosu and Hayashi 1975) against osmotic stress and acts as an osmolyte in mammalian tissues as concluded by Garcia-Perez and Burg, 1991 and Burg, 1997. Betaine is formed in cells as an oxidation product of choline and can be obtained externally from food, (McCue and Hanson, 1992). Several nutrients are including folate, vitamin B-12 and vitamin B-6 influence the metabolism of Hcys, (Selhub and Miller, 1992; Cuskelly et al., 2001 and Hu, 2002). The objective of this study is the revealence of the protein pattern after different treatments to asses the physiological state of rat as a response to this treatment. To achieve this purpose 
vertical slab electrophoresis process was performed and Polyacrylamide gel electrophoresis (PAGE) was used.

\section{MATERIAL AND METHODS}

The used albino rats Rattus norvegicus (4 weeks age and $50-60 \mathrm{~g}$ in weight) were adapted to the laboratory conditions for 7 days before the study. Animals were divided into 4 groups, group I was control, group II was treated with Trimethylglycine $(6 \mathrm{~g} / \mathrm{Kg}$ ) orally for 2 months (Wilcken et al., 1985 and Schwab et al., 2002), group III received Homocysteine (Hcys) at the dose of (0.6\%) orally for 2 months, (Masse et al., 2003) and group IV received both Homocysteine and Trimethylglycine (Hycs + Tri) orally for 2 months. Animal's autopsy took place after 2 and 8 weeks. Kidney and liver organs were prepared to biochemical studies. Proteins were separated through 8\% Polyacrylamide gel electrophoresis (PAGE) according to method of (Davis, 1964). Electrode and gel buffer and polyacrylamide stocke were prepared according (Laemmli, 1970).

Staining solution (commsie brilliant blue) was used for 12-18 hr and destaining by destain solution. The gel were photographed, scanned and analyzed using Gel Doc 2000 Bio Red system.

\section{Calculations and data analysis}

The similarity coefficient and genetic distance were calculated according to (Nei and Li,1979). As following :-

$\mathrm{S} . \mathrm{I}=2 \mathrm{Nxy} /(\mathrm{Nx}+\mathrm{Ny})$

G. $d=1-$ S. I

Where: $\mathrm{S}=$ similarity value, $\mathrm{Nx}$ and $\mathrm{Ny}$ are the number of bands in individuals $\mathrm{x}$ and $\mathrm{y}, \mathrm{N}$ is the number of shared bands. The value produced by this index ranges from zero, representing no bands sharing, to (1), representing complete identity, while $\mathrm{G}$. $\mathrm{d}$ is the genetic distance value.

\section{RESULTS}

There is no different between protein of treated and control samples as a native technique. Sodium deudosyle sulphate polyacrylamide gel electrophoresis (SDS PAGE) showed highly variation in kidney protein pattern. The tabulated data in table (1A) and fig. (1), revealed that, the total number in bands of control were 12 with $\mathrm{Rf}$ value ranged from 0.057 to 0.95 . While the total number of bands in the sacrificed animals after 2 weeks were 25, 22 and 22 for Tri, Hcys and Tri + Hcys, respectively. Data represented that, bands number 1, 4, 10, 11, 15, 16, 20, 22, 25, 26 and 27 were common bands with average M.W. 278.64, 157.07, 59.37, 52.39, 39.31, 35.13, 29.24, $24.49,20.86,20.04$ and $18.87 \mathrm{~K}$.d. for control respectively.

No characteristic bands for the control, while the bands no. 3, 8, 9, 17 and 19 with $\mathrm{Rf}$ value $0.091,0.30,0.33,0.65$ and 0.69 and M.W. 214.29, 69.5, 66.5, 34 and 31.75 K.d. were characteristic bands for the Tri treated animals. Band no. 18 appeared only in Hcys and Tri + Hcys treated animals with Rf value 0.66. Densitometric scanning of electrophoresis showed that, the $7^{\text {th }}$ band in Tri + Hcys treated group had the highest density than the others. The quantitative mutation was recorded according to band $\%$ related to control samples. The highest quantitative mutation was recorded in band no. 15 in Tri + Hcys samples with M.W. 39.75 K.d. equal 42.6 times of control. In table (1B) and fig. (1), the total number of bands in treated animals after 8 weeks were 14, 22 and 22 for Tri, Hcys and Tri + Hcys respectively. Bands no. 1, 4, 
$11,15,19,21,24,25$ and 26 were common bands in all treated animal and control. Bands no. 10 and 16 with M.W. 59.583 and 35.25 K.d. specific to the control. Band no. 5 with M.W. 110 K.d. specific to Tri treated animals and recorded high denisty, while band no. 2 with M.W. 242.86 K.d specific to Tri + Hcys treated animals. There was a quantitative mutation recorded in band no. 11 in Hcys treated group with M.W. 52.66 K.d. reached to 11.5 times if compared to control.

Table (1A) : Molecular weight (M.W.), amxount (\%) and rate of flow (RF) for kidney of Rattus norvegicus fractionated protein for the treated and control groups after 2 weeks.

\begin{tabular}{|c|c|c|c|c|c|c|c|c|c|c|c|c|c|}
\hline \multirow{2}{*}{ Samples } & \multicolumn{3}{|c|}{ Control } & \multicolumn{3}{|c|}{ Tri group } & \multicolumn{3}{|c|}{ Hcys group } & \multicolumn{3}{|c|}{$\overline{\text { Tri+Hcys group }}$} & \multirow{2}{*}{$\begin{array}{l}\text { Average } \\
\text { M.W. }\end{array}$} \\
\hline & M.W. & $\%$ & $\mathrm{RF}$ & M.W. & $\%$ & $\mathrm{RF}$ & M.W. & $\%$ & $\mathrm{RF}$ & M.W. & $\%$ & $\mathrm{RF}$ & \\
\hline 1* & 278.57 & 1 & 0.057 & 278.71 & 0.4 & 0.057 & 278.71 & 0.9 & 0.057 & 278.57 & 1.8 & 0.057 & 278.64 \\
\hline 2 & 221.43 & 1.8 & 0.088 & - & - & - & 221.43 & 5.3 & 0.088 & 221.43 & 4.3 & 0.088 & 221.43 \\
\hline 3 & - & - & - & 214.29 & 4.3 & 0.091 & - & - & - & - & - & - & 214.29 \\
\hline $4 *$ & 157.14 & 8.3 & 0.13 & 157.14 & 9.8 & 0.13 & 157 & 9.9 & 0.13 & 157 & 8.9 & 0.13 & 157.07 \\
\hline 5 & - & - & - & 105 & 11.3 & 0.21 & 106.67 & 12.2 & 0.21 & 106.67 & 10.6 & 0.21 & 106.11 \\
\hline 6 & - & - & - & 93.333 & 0.4 & 0.23 & 93.333 & 2.8 & 0.23 & 93.333 & 13.2 & 0.23 & 93.33 \\
\hline 7 & - & - & - & 76.923 & 3.9 & 0.23 & 75.769 & 5.7 & 0.28 & 76.923 & 17.3 & 0.28 & 76.53 \\
\hline 8 & - & - & - & 69.5 & 1.3 & 0.30 & - & - & - & - & - & - & 69.5 \\
\hline 9 & - & - & - & 66.5 & 2.9 & 0.33 & - & - & - & - & - & - & 66.5 \\
\hline $10^{*}$ & 59.583 & 9.3 & 0.38 & 59.167 & 0.7 & 0.38 & 59.583 & 0.8 & 0.38 & 59.167 & 1.3 & 0.38 & 59.37 \\
\hline $11^{*}$ & 52.5 & 12.7 & 0.45 & 52.083 & 2.5 & 0.45 & 52.5 & 2.7 & 0.45 & 52.5 & 2.1 & 0.45 & 52.39 \\
\hline 12 & - & - & - & 50 & 0.9 & 0.47 & 50 & 1.4 & 0.47 & 50.417 & 1.2 & 0.46 & 50.13 \\
\hline 13 & - & - & - & 46.4 & 1.7 & 0.5 & 46.4 & 1.7 & 0.5 & 46.4 & 1.8 & 0.5 & 46.4 \\
\hline 14 & - & - & - & 44.6 & 1.5 & 0.53 & 44.6 & 3.3 & 0.53 & 44.6 & 2.4 & 0.53 & 44.6 \\
\hline $15^{*}$ & 39 & 12.8 & 0.57 & 39 & 5.2 & 0.57 & 39.75 & 3.2 & 0.57 & 39.5 & 0.3 & 0.57 & 39.31 \\
\hline $16^{*}$ & 35.25 & 14.6 & 0.64 & 35.25 & 1 & 0.64 & 35 & 0.4 & 0.64 & 35.75 & 3.4 & 0.64 & 35.13 \\
\hline 17 & - & - & - & 34 & 0.3 & 0.65 & - & - & - & - & - & - & 34 \\
\hline 18 & - & - & - & - & - & - & 33.75 & 0.8 & 0.66 & 33.75 & 0.8 & 0.66 & 33.75 \\
\hline 19 & - & - & - & 31.75 & 3.2 & 0.69 & - & - & - & - & - & - & 31.75 \\
\hline $20^{*}$ & 29.038 & 17.2 & 0.73 & 29.038 & 1.4 & 0.73 & 29.038 & 4.2 & 0.73 & 29.846 & 3.2 & 0.73 & 29.24 \\
\hline 21 & - & - & - & 27.885 & 0.6 & 0.76 & 27.885 & 1.2 & 0.76 & 27.692 & 1.2 & 0.76 & 27.82 \\
\hline $22^{*}$ & 24 & 3.8 & 0.82 & 24.828 & 3.3 & 0.82 & 24.655 & 3.5 & 0.82 & 24.483 & 3.2 & 0.82 & 24.49 \\
\hline 23 & - & - & - & 23.448 & 5.6 & 0.85 & 23.448 & 5.8 & 0.85 & 23.276 & 9.5 & 0.85 & 23.39 \\
\hline 24 & - & - & - & 22.414 & 8.2 & 0.87 & 22.414 & 8.5 & 0.87 & 22.241 & 10.5 & 0.87 & 22.35 \\
\hline $25^{*}$ & 20.862 & 4.5 & 0.91 & 20.862 & 13.2 & 0.91 & 20.862 & 9.1 & 0.91 & 20.862 & 0.9 & 0.91 & 20.86 \\
\hline $26^{*}$ & 20 & 5.5 & 0.92 & 20 & 15.2 & 0.92 & 20.172 & 15.4 & 0.92 & 20 & 1.2 & 0.92 & 20.04 \\
\hline $27 *$ & 18.966 & 8.5 & 0.95 & 18.793 & 1.2 & 0.95 & 18.793 & 1.2 & 0.95 & 18.966 & 0.9 & 0.95 & 18.87 \\
\hline
\end{tabular}

$*$ indicated for common bands $\%=$ Amount percent

$\mathrm{Rf}=$ Rate of flow.

Table (1B): Molecular weight (M.W.), amount (\%) and rate of flow (RF) of kidney fractionated protein for the treated and control groups of Rattus norvegicus after 8 weeks.

\begin{tabular}{|c|c|c|c|c|c|c|c|c|c|c|c|c|c|}
\hline \multirow{2}{*}{ Rows } & \multicolumn{3}{|c|}{ Control } & \multicolumn{3}{|c|}{ Tri group } & \multicolumn{3}{|c|}{ Hcys group } & \multicolumn{3}{|c|}{ Tri+Hcys group } & \multirow{2}{*}{$\begin{array}{c}\text { Average } \\
\text { M.W }\end{array}$} \\
\hline & M.W. & $\%$ & $\mathrm{RF}$ & M.W.. & $\%$ & $\mathrm{RF}$ & M.W. & $\%$ & $\mathrm{RF}$ & M.W. & $\%$ & $\mathrm{RF}$ & \\
\hline $1^{*}$ & 278.57 & 0.9 & 0.057 & 278.57 & 3.9 & 0.057 & 278.71 & 0.8 & 0.57 & 278.57 & 1.3 & 0.057 & 278.60 \\
\hline 2 & - & - & - & - & - & - & - & - & - & 242.86 & 6.3 & 0.076 & 242.86 \\
\hline 3 & 221.43 & 1.8 & 0.081 & 221.57 & 7.5 & 0.081 & 221.71 & 5.5 & 0.08 & - & - & - & 221.57 \\
\hline $4 *$ & 157.14 & 8.3 & 30.13 & 157 & 8.4 & 0.13 & 157 & 10.7 & 0.13 & 157.14 & 12.6 & 0.13 & 157.07 \\
\hline 5 & - & - & - & 110 & 35.4 & 0.19 & - & - & - & - & - & - & 110 \\
\hline 6 & - & - & - & - & - & - & 108.33 & 12.7 & 0.20 & 108.33 & 14.8 & 0.2 & 108.33 \\
\hline 7 & - & - & - & - & - & - & 95 & 15.4 & 0.23 & 96.662 & 18.2 & 0.23 & 95.83 \\
\hline 8 & - & - & - & - & - & - & 79.231 & 19.2 & 0.27 & 79.231 & 4.1 & 0.27 & 79.23 \\
\hline 9 & - & - & - & - & - & - & 66 & 5.3 & 0.33 & 66.5 & 4.7 & 0.33 & 66.25 \\
\hline 10 & 59.583 & 9.3 & 0.38 & - & - & - & - & - & - & - & - & - & 59.58 \\
\hline $11^{*}$ & 52.5 & 12.7 & 0.44 & 52.917 & 2 & 0.44 & 52.917 & 1.1 & 0.44 & 52.333 & 3.8 & 0.44 & 52.66 \\
\hline 12 & - & - & - & - & - & - & 50.417 & 1.2 & 0.46 & 50.417 & 0.6 & 0.46 & 50.41 \\
\hline 13 & - & - & - & - & - & - & 48 & 1.2 & 0.49 & 47.6 & 2.9 & 0.49 & 47.8 \\
\hline 14 & - & - & - & - & - & - & 44.6 & 4.3 & 0.51 & 44.6 & 3.7 & 0.51 & 44.6 \\
\hline $15^{*}$ & 39 & 12.9 & 0.57 & 39.25 & 11.1 & 0.57 & 39.5 & 4.4 & 0.57 & 39.5 & 4.2 & 0.57 & 39.31 \\
\hline 16 & 35.25 & 14.6 & 0.64 & - & - & - & - & - & - & - & - & - & 35.25 \\
\hline 17 & - & - & - & 34.5 & 5.4 & 0.65 & 34.5 & 1 & 0.65 & 34.5 & 1.4 & 0.65 & 34.5 \\
\hline 18 & - & - & - & 33.5 & 1.4 & 0.67 & 33.25 & 0.4 & 0.67 & 33.25 & 1.1 & 0.67 & 33.33 \\
\hline $19^{*}$ & 29.038 & 17.2 & 0.73 & 29.231 & 4.3 & 0.73 & 29.231 & 4.2 & 0.73 & 29.423 & 3.8 & 0.73 & 29.23 \\
\hline 20 & - & - & - & - & - & - & 28.077 & 0.5 & 0.75 & 28.269 & 4.1 & 0.75 & 28.17 \\
\hline $21^{*}$ & 24 & 3.9 & 0.83 & 24.31 & 12.2 & 0.83 & 24.31 & 5.2 & 0.83 & 24.138 & 3.1 & 0.83 & 24.18 \\
\hline 22 & - & - & - & - & - & - & 23.448 & 0.2 & 0.85 & 23.276 & 2.7 & 0.85 & 23.36 \\
\hline 23 & - & - & - & 22.414 & 0.3 & 0.87 & 22.414 & 3.2 & 0.87 & 22.241 & 2.3 & 0.87 & 22.35 \\
\hline $24 *$ & 20.862 & 4.6 & 0.91 & 20.69 & 4.3 & 0.91 & 20.862 & 0.8 & 0.91 & 20.69 & 1.3 & 0.91 & 20.77 \\
\hline $25^{*}$ & 20 & 5.5 & 0.92 & 20 & 2.2 & 0.92 & 20.172 & 1.2 & 0.92 & 20 & 1.2 & 0.92 & 20.04 \\
\hline $26^{*}$ & 19.966 & 8.3 & 0.95 & 19.966 & 1.6 & 0.95 & 19.31 & 1.5 & 0.95 & 19.138 & 1.8 & 0.95 & 19.59 \\
\hline
\end{tabular}


The similarity index (S.I.) and genetic distance (G.D.) at the epigenetic level were recorded between control and other treated animals, table (1C). The highest value of 1 was found between Tri + Hcys and Hcys group, while the lowest value was 0.54 found between Tri and control group. The highest G.d. value of 0.46 was found between control and Tri group, while the lowest value of 0 was found between Hcys and Tri + Hcys group. From data in table (1D), the highest S.I. of 0.95 was found between Tri + Hcys and Hcys group, while the lowest value of 0.54 was found between Tri + Hcys and control group. The highest G.d. value of 0.46 was found between control and Tri + Hcys group, while the lowest value of 0.24 was found between control and Tri group.

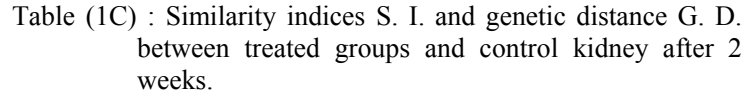
between treated groups and control kidney after 2 weeks.

\begin{tabular}{|c||c|c|c|c|}
\hline S. I. & Control & $\begin{array}{c}\text { Tri } \\
\text { group }\end{array}$ & $\begin{array}{c}\text { Hcys } \\
\text { group }\end{array}$ & $\begin{array}{c}\text { Tri+Hcys } \\
\text { group }\end{array}$ \\
\hline \hline Control & - & 0.54 & 0.70 & 0.70 \\
\hline Tri group & 0.46 & - & 0.78 & 0.85 \\
\hline $\begin{array}{c}\text { Hcys } \\
\text { group }\end{array}$ & 0.30 & 0.22 & - & 1 \\
\hline $\begin{array}{c}\text { Tri+Hcys } \\
\text { group }\end{array}$ & 0.30 & 0.15 & 0 & - \\
\hline
\end{tabular}

Table (1D) : Similarity indices S. I. and genetic distance G. $\mathrm{D}$ between treated groups and control of kidney after 8 weeks.

\begin{tabular}{|c||c|c|c|c|}
\hline S. I. & Control & $\begin{array}{c}\text { Tri } \\
\text { group }\end{array}$ & $\begin{array}{c}\text { Hcys } \\
\text { group }\end{array}$ & $\begin{array}{c}\text { Tri+Hcys } \\
\text { group }\end{array}$ \\
\hline \hline Control & - & 0.76 & 0.60 & 0.54 \\
\hline Tri group & 0.24 & - & 0.75 & 0.77 \\
\hline $\begin{array}{c}\text { Hcys } \\
\text { group }\end{array}$ & 0.40 & 0.25 & - & 0.95 \\
\hline $\begin{array}{c}\text { Tri+Hcys } \\
\text { group }\end{array}$ & 0.46 & 0.23 & 0.05 & - \\
\hline
\end{tabular}

Table (2A \& 2B) and fig. (2), summarized the data collected from liver electrophoresis of all groups. In table (2A), six types of protein from each group under study were produced except for control, it was 11 bands. There were 4 common bands were no. 3, 8, 12 and 13 with average M.W. 138, 44.22, 25 and 17.49 K.d for control group. In control group, there were 6 characteristic bands, were appeared their no. were 4, 5, 6, 9, 10 and 11, while band no 7 with M.W. 50 K.d was disappeared. Band no. 1 was a common band between Hcys and Tri + Hcys treated groups with Rf value 0.049 for both. Also band no. 2 was a common band between control group and Tri treated group with Rf value 0.053 for both. Densitometric scanning of electrophoresis showed that bands no. 3 and 8 in all three treared groups had higher density than others, table (2A). It is good to mention that, protein with M.W. 17.077 in control samples has a small band \% (0.3) compared to Tri samples (14.8), i.e 49.3 times as compared with control samples.

In table (2B), the total number of protein types in control group bands, Tri treated group, Hcys treated group and Tri + Hcys treated group were 11, 14, 12 and 12 respectively. Bands no. 3, 5, 6, 7, 10, 11, 12 and 15 with average M.W. 140, 85.32, $75.02,56.43,44.06,36.43,32.52$ and $23.29 \mathrm{~K} . \mathrm{d}$ were common bands for all 4 groups. There was one characteristic band for control group, it was no. 2 with M.W. 221.43 K.d. The rest treated groups agree with each other in all bands, except Tri treated group which contained 2 characteristic bands, their number were 1 and 9 with M.W 235.71 and 49.474 K.d respectively. Densitomeric scanning of electrophorogram showed that band no. 12 in Hcys treated group and band no. 15 in both Tri treated group and Tri + Hcys treated group had higher density than other bands. The highest quantitative mutation recorded in band no. 10 in Hcys samples, it equal 6.7 times if compared to control samples. 
Epigenetic patteren of albino rat after treatment with Homocysteine and Trimethylglycine.171

Table (2A) : Molecular weight (M.W.), amount (\%) and rate of flow (RF) of liver fractionated protein for the treated and control groups of Rattus norvegicus after 2 weeks

\begin{tabular}{|c|c|c|c|c|c|c|c|c|c|c|c|c|c|}
\hline \multirow{2}{*}{ Rows } & \multicolumn{3}{|c|}{ Control } & \multicolumn{3}{|c|}{ Tri group } & \multicolumn{3}{|c|}{ Hcys group } & \multicolumn{3}{|c|}{ Tri+Hcys group } & \multirow[b]{2}{*}{$\begin{array}{c}\text { Average } \\
\text { M.W }\end{array}$} \\
\hline & M.W. & $\%$ & $\mathrm{RF}$ & M.W. & $\%$ & $\mathrm{RF}$ & M.W. & $\%$ & $\mathrm{RF}$ & M.W. & $\%$ & $\mathrm{RF}$ & \\
\hline 1 & - & - & - & - & - & - & 228.57 & 11.4 & $\begin{array}{c}0.04 \\
9\end{array}$ & 228.57 & 9.3 & $\begin{array}{c}0.04 \\
9\end{array}$ & 228.57 \\
\hline 2 & 221.43 & 7.7 & $\begin{array}{c}0.05 \\
3 \\
\end{array}$ & 221.43 & 9.5 & $\begin{array}{c}0.05 \\
3\end{array}$ & - & - & - & - & - & - & 221.43 \\
\hline 3* & 138 & 13.8 & 0.11 & 138 & 35.1 & 0.11 & 138 & 33.7 & 0.11 & 138 & 42.2 & 0.11 & 138 \\
\hline 4 & 85 & 7.1 & 0.21 & - & - & - & - & - & - & - & - & - & 85 \\
\hline 5 & 69.091 & 10.5 & 0.27 & - & - & - & - & - & - & - & - & - & 69.09 \\
\hline 6 & 54.848 & 3.7 & 0.36 & - & - & - & - & - & - & - & - & - & 54.84 \\
\hline 7 & - & - & - & 50 & 7.1 & 0.42 & 50 & 1.1 & 0.42 & 50 & 0.6 & 0.42 & 50 \\
\hline 8* & 44.105 & 9.4 & 0.48 & 44.263 & 30.2 & 0.48 & 44.263 & 38.7 & 0.48 & 44.263 & 29.6 & 0.48 & 44.22 \\
\hline 9 & 35.833 & 17.8 & 0.61 & - & - & - & - & - & - & - & - & - & 35.83 \\
\hline 10 & 33.056 & 9.7 & 0.64 & - & - & - & - & - & - & - & - & - & 33.05 \\
\hline 11 & 28.25 & 0.7 & 0.71 & - & - & - & - & - & - & - & - & - & 28.25 \\
\hline $12 *$ & 25.182 & 19.3 & 0.75 & 25 & 3.3 & 0.75 & 25 & 5.7 & 0.75 & 25 & 4.9 & 0.75 & 25.04 \\
\hline $13^{*}$ & 17.077 & 0.3 & 0.88 & 17.885 & 14.8 & 0.88 & 17.692 & 9.4 & 0.88 & 17.308 & 13.4 & 0.88 & 17.49 \\
\hline
\end{tabular}

* indicated to common bands $\%=$ Band percent $\quad \mathrm{Rf}=$ Fractionated protein.

Table (2B): Molecular weight (M.W.), amount (\%) and rate of flow (RF) of liver fractionated protein for the treated and control groups of Rattus norvegicus after 8 weeks.

\begin{tabular}{|c||c|c|c||c|c||c|c|c||c||c||} 
& \multicolumn{3}{l||}{ Hcys group } & \multicolumn{3}{||}{ Tri+Hcys group } \\
Average \\
M.W
\end{tabular}

From table (2C), the highest S. I. recorded between Tri + Hcys group and Hcys group, it reached one, while the smallest value of 0.44 was found between Hcys $\&$ Tri + Hcys and control group. Data from table (2D) revealed that, the smallest G.d. value of 0.05 was found between Hcys and Tri + Hcys group.

Table (2C) : Similarity indices S. I. and genetic distance G. D. between treated groups and control of liver after2 weeks.

\begin{tabular}{|c||c|c|c|c|}
\hline S. I. & Control & $\begin{array}{c}\text { Tri } \\
\text { group }\end{array}$ & $\begin{array}{c}\text { Hcys } \\
\text { group }\end{array}$ & $\begin{array}{c}\text { Tri+Hcys } \\
\text { group }\end{array}$ \\
\hline \hline Control & - & 0.55 & 0.44 & 0.44 \\
\hline Tri group & 0.45 & - & 0.83 & 0.83 \\
\hline $\begin{array}{c}\text { Hcys } \\
\text { group }\end{array}$ & 0.56 & 0.17 & & 1 \\
\hline $\begin{array}{c}\text { Tri+Hcys } \\
\text { group }\end{array}$ & 0.56 & 0.17 & 0 & - \\
\hline
\end{tabular}

Table (2D) : Similarity indices S. I. and genetic distance G. D. between treated groups and control of liver after 8 weeks.

\begin{tabular}{|c||c|c|c|c|}
\hline S. I. & Control & $\begin{array}{c}\text { Tri } \\
\text { group }\end{array}$ & $\begin{array}{c}\text { Hcys } \\
\text { group }\end{array}$ & $\begin{array}{c}\text { Tri+Hcys } \\
\text { group }\end{array}$ \\
\hline \hline Control & - & 0.38 & 0.66 & 0.69 \\
\hline Tri group & 0.62 & - & 0.92 & 0.88 \\
\hline $\begin{array}{c}\text { Hcys } \\
\text { group }\end{array}$ & 0.34 & 0.08 & - & 0.95 \\
\hline $\begin{array}{c}\text { Tri+Hcys } \\
\text { group }\end{array}$ & 0.31 & 0.12 & 0.05 & - \\
\hline
\end{tabular}




\section{DISCUSSION}

Nine new types of protein with average M.W. 106.11, 93.33, 76.43, 50.13, 46.4, 44.6, 27.82, 23.39 and $22.35 \mathrm{~K} . \mathrm{d}$ were produced in the treated groups, as in table (1A) and three new types of protein with average M.W. 34.5, 33.33 and 22.35 K.d were produced in treated groups, as in table (1B), which mean the activation of some genes to produce these types of protein (Holdane, 1937).

There were six types of protein with M. W. 85, 69.09, 54.848, 35.83, 33.05 and $28.25 \mathrm{~K} . \mathrm{d}$, as showed in table 2A, and three types of protein with M.W. 221.43, 28.25 and 18.07 K.d, (table 2B), were disappeared from all treated groups, this mean the inhibition of their genes to produce these types of protein. While there was one protein type with M.W. 50 K.d, (table 2A), and four types of protein with average M.W. 126.19, 50.90, 29.16 and 14.16 K.d were appeared in treated groups, which indicated that the activation of their genes to produce these types of protein. hHcys is very dangerous for the body and toxic for endothelium, it enhanced vascular smooth muscle cell proliferation, (Satta et al., 2006). In the present study the protein electrophoresis revealed differences between control and the treated groups and also between treated groups themselves. This is due to the production or the disappearance of different types of proteins.

Finkelstein et al., 1971; Breska and Garrow 1999; Castro et al., 2002 and Yap 2005, indicated that, the Betaine - homocysteine $-\mathrm{S}$ - methyltransferase 1 (BHMT 1) protein, with M.W. 44.9 K.d and the Betaine - homocysteine - S - methyltransferase 2 (BHMT 2) protein with M.W. 39.9 K.d were involved in the regulation of Hcys metabolism. Betaine and Hcys were converted to dimethylglycine and methionine respectively. This reaction is also required for the irreversible oxidation of choline. These two proteins were existed already in this study with M.W. 44.6 K.d in all treated groups, which represented to (BHMT1) protein. Also the common protein with M.W. $39.31 \mathrm{~K} . d$, represented the BHMT2 protein, the two types of protein BHMT1 and BHMT2 were important in regulation of Hcys metabolism. The protein with M.W. 44.6 K.d which presented in Hcys group and Tri + Hcys group (band no 14) refered to the presence of BMHT1 protein and absent from Tri group indicates that, betaine supplementation decreased the plasma Hcys concentration as resulted by Brouwer et al., 2000; Tangerman et al., 2000 and Schwab et al., 2002. From other obtained data, the protein of BHMT1 was represented in all treated groups with average M.W. 44.2 K.d and average M.W. 44.06 K.d in all treated groups. Finkelstein 2007, indicated that, all tissues posses the methionine cycle with methyltetrahydrofolate as the methyl donor, but only kidney, liver, pancrease, intestine and brain also contain the transsulfuration pathway. Also, Treberg and Driedzic (2007), suggested that, the kidney and liver appear to be the major sites of betaine synthesis.

Finally, it would be concluded that the protein pattern is changed in each of kidney and liver and quantitative mutation recorded in all tables leading to change in homocysteine pattern which causes different behavioral pattern in each of control and the treated groups.

\section{ACKNOWLEDGEMENT}

I am greatly indebted to Prof. Dr. Saadya M. El-Bermawy, Professor of Insect Physiology, Biological Science and Geology Department, Faculty of Education, Ain Shams University, Cairo, Egypt for his encouragement and critical reading of the manuscript. 


\section{REFERENCES}

Breska, A. P. and Garrow, T. A. (1999). Recombinant human liver betainehomocysteine S-methyltransferase: identification of three cysteine residues critical for zink binding. Bioch. 38: $13991-13997$.

Brouwer, I. A.; Verhoef, P. and Boers, G. H (2000). Betaine supplementation and plasma homocysteine in healthy volunteers. Arch. Intern. Med. 160: $2546-$ 2547 Burg, M. B. (1997). Renal osmoregulatory transport of compatible organic osmolytes. Curr. Opin.Nephrol. Hypertens., 6: $430-433$.

Castro, C.; Breksa, A. P.; Salisbury, E. M. and Garrow, T. A. (2002). Betaine homocysteine $\mathrm{S}$ - methyltransferase (BHMT) transcription is inhibited by $\mathrm{S}-$ adenosylmethionine (AdoMet). In: Chemistry and Biology of Pteridines and Folates pp. $549-556$.

Cuskelly, G. J.; Stacpool, P. W.; Williamson, J.; Baumgartner, T. G. and Gregory J. F. (2001). "Deficiencies of folate and vitamin B 6 exert distinct effects on homocysteine, serine and methionine kinetics." Am. J. Physiol. Endocrinol. Metab. 281: $1182-1190$.

Davis, B. J. (1964). "Disc electrophoresis in methods and application to human serum protein." Ann. N. Y., Acad. Sci., 121: $404-427$.

Finkelstein, J. D. (2007). Metabolic regulatory properties of S- adenosylmethionine and S- adenosylhomocysteine. Clin. Chem. Lab. Med., (45112): 1694 - 1699 Finkelstein, J. D; Kyle, W. E. and Harris, B. J. (1971): Methionine metabolism in mammals. Regulation of homocysteine methyltransferase in rat tissue Arch. Biochem. Biophys., 146: $84-92$.

Garcia-Perez, A. and Burg, M. B.(1991).Renal medullary organic osmolytes. Physiol. Rev., 71: $1081-1115$.

Holdane, J. B. S. (1937). Perspective in biochemistry. Cambridge Univ. Press, P.1-10.

House, J. D.; Margaret E. B.; and John, T. B. (1997). Renal homocysteine metabolism. Contrib. Nrphrol., 121: $79-84$.

House, J. D.; Jacobs R. L., Stesd L. M., Brosnan M. E., Brosnan J. T. (1999). Regulation oh homocysteine metabolism. Adv. Enzyme. Regul., 39 : 69 - 91.

$\mathrm{Hu}$, F. B. (2002); Dietary pattern analysis: a new direction in nutritional epidemiology. Curr. Opin. Lipidol., $13: 3-7$.

Konosu, S. and Hayashi, T. (1975). Determination of beta-alanine and glycine betaine in some marine invertebrates. Bull. Jpn. Soc. Fish., 41: 743 - 746.

Laemmili, U. Q. (1970). Cleavage of structural proteins during assembly of head bactriophage T4. Nature, 2227: 680 - 685

Li, N.; Li C.; Rachel, W. M. and Pin-Lan, L. (2006). Hyperhomocysteinemia associated with decreased renal trassulfuration activity in Dahl S Rats. Hypertention , $47: 1094$

Masse, A. G.; Adele, L. B.; Israel, Z.; Peter H.; Sharon, M. D.; David, S. H .and David, E. C. (2003). Chemical and biomechanical characterization of hyperhomocysteinemic bone disease in an animal model BMC Musculoskeletal Disord., 4: 1 - 14.

McCue, K. F, and Hanson, A. D. (1992). Salt - inducible betaine aldehyde dehydrogenase from sugar beet: cDNA cloning and expression. Plant Mol. Biol., 18 1- 11

Nei, M. and Li, W. S. (1979). Mathematical model for studing genetic variation in terms of restriction endonuclease. Proc. Natl. Acad. Sci., USA, 76: 5269 5273 . 
Rozwadowski, K. L.; Khachatourians, G. G. and Selvaraj, G. (1991). Choline oxidase a catabolic enzyme in Arthrobacter pascens, facilities adaption to osmotic stress in Escherichia coli. J. Bacteriol., 173: 472 - 478.

Sakamoto, A. and Murata, N. (2000). Genetic engineering of glycine betaine synthesis in plants: current status and implications for enhancement of stress tolerance. J. Exp. Bot. 51: $81-88$.

Satta E.; Perna A. F.; Lombardi C.; Acanfora F.; Violetti E.; Romano M. M; Capasso R.; Pisano M.; Paduano F.; and De Santo N. G. (2006); Hyperhomocyteinemia in chronic renal failure. G. Ital. Nefrol., 23 (5): 480 - 489.

Schwab, U.; Anneli, T.; Leena, T.; George, A.; Markku, S.; Antti, A. and Matti, U. (2002). Betaine supplementation decreases plasma homocysteine concentration but does not affect body weight, body composition or resting energy expenditure in human subjects. Am. J. Clin. Nutr., $76: 961-967$.

Selhub, J. and Miller, J. W. (1992). The pathogenesis of homocysteinemia: interruption of the coordinate regulation by S- adenosylmethionine of the remethylation and transsulfuration of homocysteine. Am. J. Clin. Nutr., 55: $131-138$.

Stead, L. M.; Margrate, E. B. and John, T. B. (2000). Characterization of homocysteine metabolism in the rat liver. Biochem. J. 350: 685-692.

Tangerman, A.; Wilcken, B.; Levy, H. L.; Boers, G. H. and Mudd, S. H. (2000). "Methionine transamination in patients with homocystinuria due to cystathionine beta - synthase deficiency." Metabolism, 49: 1071 - 1077.

Treberg, J. R. and Driedzic, W. R. (2007). The accumulation and synthesis of betaine in water skate (Leucoraja ocellate). Comp. Biochem. Physiol. A. Mol. Integr. Physiol., 147 (2) : $475-483$.

Wilcken, D. E.: Dudman, N. P. and Tyrrell P. A. (1985). Homocysteinuria due to cystathionine beta - stnthase deficiency - the effects of betaine treatment in pyridoxine-responsive patients. Metabolism, 34: $1115-1121$.

Yap, S. (2005). Homocysteinuria due to cystathionine beta-stnthase deficiency. Orphanet encyclopedia. 
Epigenetic patteren of albino rat after treatment with Homocysteine and Trimethylglycine.175

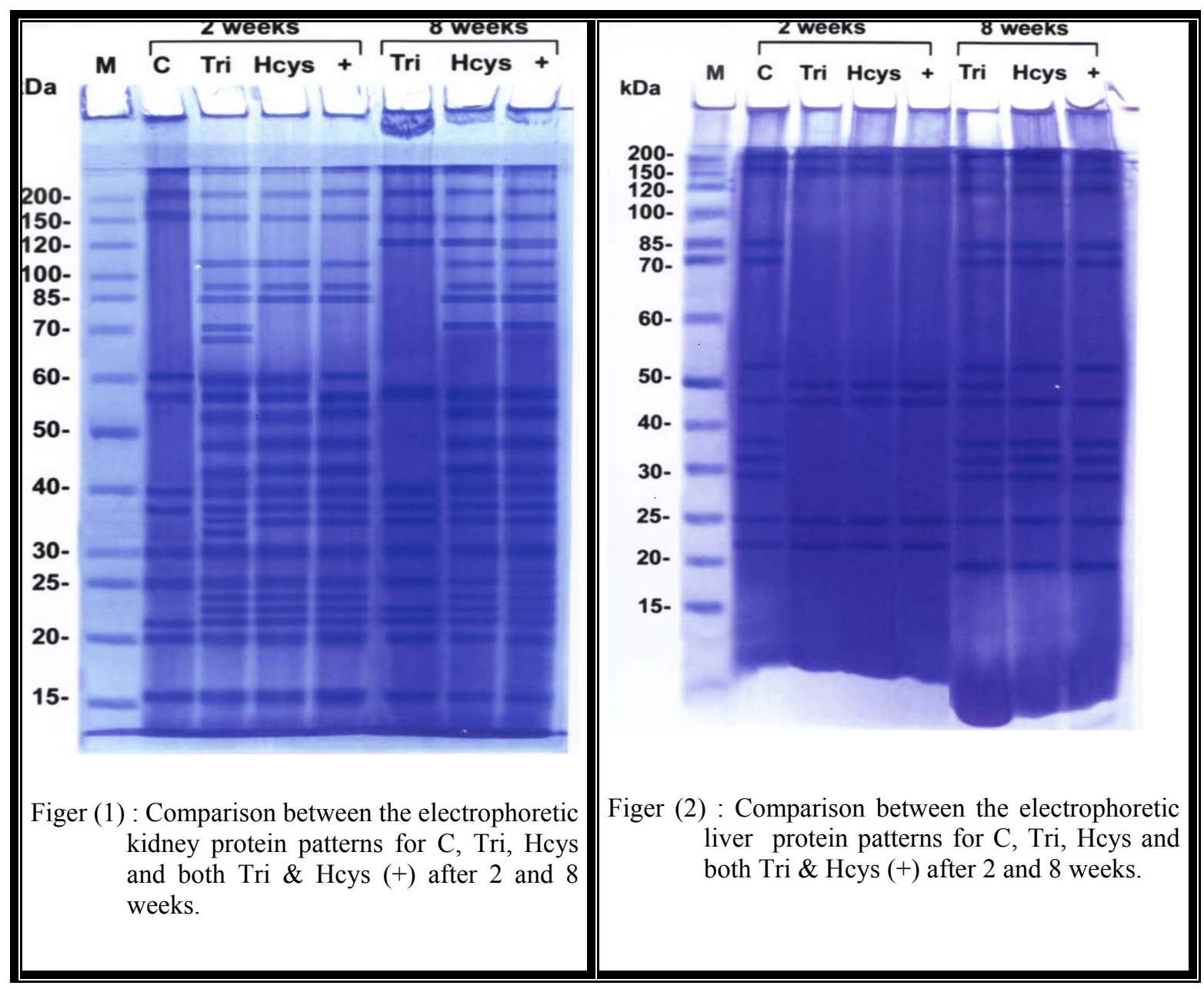




\title{
ARABIC SUMMERY
}

\section{النموذج تحت الوراثي (البروتين) في الفئران البيضاء راتس نورفيجيكاس بعد المعاملة بالهوموسيستين و تيلاثي ميثيل جليسين التين}

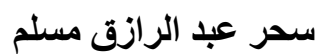 \\ قسم علم الحيو ان - كلبة البنات للعلوم و التربية و الأداب - جامعة عين شمس
}

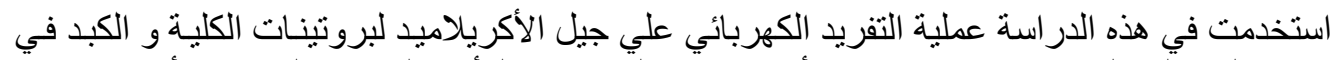

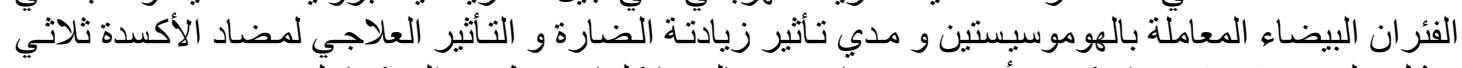

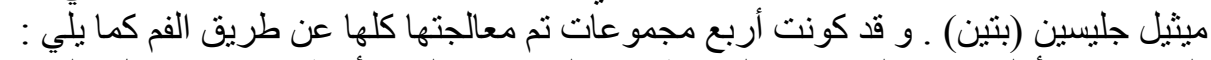

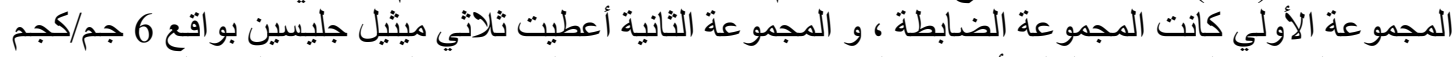

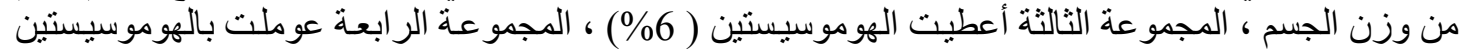
و ثلاثي ميثيل جليسين معا يو ميا طو ال فترة التجربة و التي استمرت لتون لمدة شهرين.

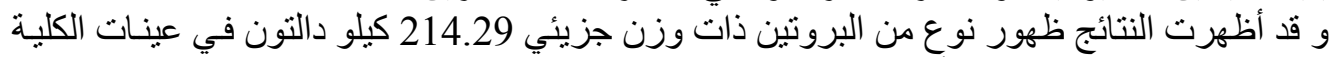

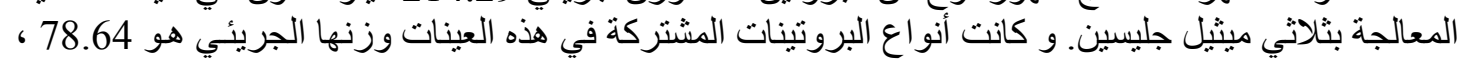

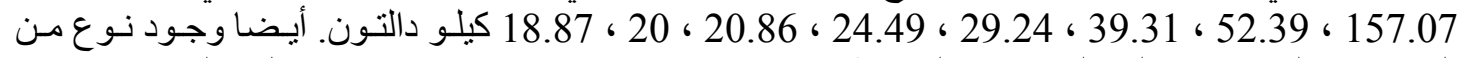

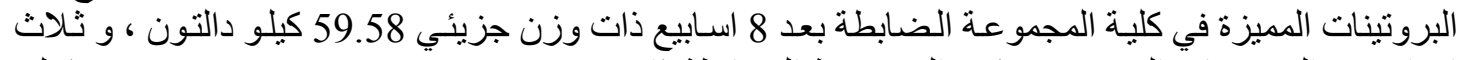

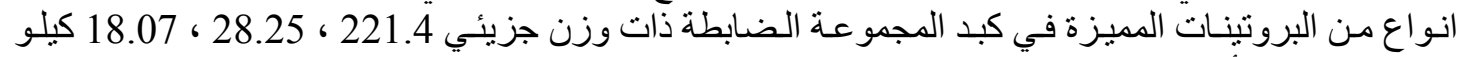

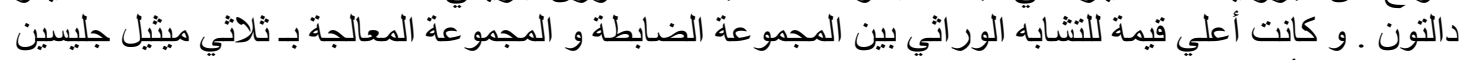

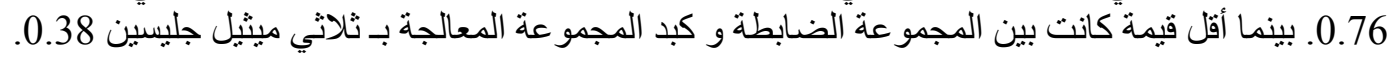

